\title{
Eestlaste argielutavadest
}

Avaldatud: Vanadest eesti rahvakommetest / koost. Ülo Tedre. 2., täiendatud ja parandatud trükk, Tallinn: Perioodika, 1991, lk 77-111

\section{1.}

Veel möödunud sajandil saatsid kogu inimtegevust traditsioonilised tavad. Me oleme neid harjunud jälgima ja pidama kalendaarsete tähtpäevade puhul. Ka inimelu murranguliste momentide puhul - nagu sündimine, abiellumine, suremine - ei hämmasta meid käibelolevad või käibelolnud tavad. Vähem, ent ikkagi üht-teist, teame töödega seotud tavadest (pikka aega oli tuntud esimeselt tööpäevalt tuleva töötaja kastmine - kasteti karjust esimese karjatamispäeva õhtul, kündjat, kes tuli esimeselt künnilt jpt.). Kuid kindlaks kujunenud kombed saatsid ka täiesti tavalist igapäevaelu - söögitegemist ja söömist, teekäimist ja küllaminemist, pesupesemist ja põrandapühkimist, istumist ja astumist. Seesuguste igapäevatavade uskumuslik taust on enamasti hääbunud ja vististi juba üsnagi ammu. Igapäevatavad seonduvadki rohkem rahva eetiliste tõekspidamiste kui uskumustega, kuigi viimaseidki ei saa eirata.

Nagu inimelu ise nii ka seda kaasavad kombed on väga mitmepalgelised. Üks ja sama tegu võib saada täiesti erineva tõlgitsuse, olenevalt teo tegijast (mees-naine, abielus-vallaline, täisealine-laps), tegemise ajast (nädalapäevast, kuufaasist), teo tulemusest või tagajärjest. Seetõttu on ka täieliku ülevaate andmine igapäeva tavadest üsnagi keerukas, igal juhul töömahukas. Kuigi Kirjandusmuuseumi rahvaluuleosakonna uskumuste ja kommete kartoteegid on põhiliselt heas korras, puuduvad seal siiski viited analoogilistele või lähedastele tavadele. Neid võib muidugi ise otsida, lähtudes teisest oletatavast märksõnast. See otsimine ongi töömahukas ega anna alati soovitud tulemusi. Kui järgnev ülevaade tundub lugejale liiga põgus, siis olgu eelnev arutlus selgituseks sellele esimesele katsele vaadelda süsteemselt igapäevase eluga seotud eesti tavasid.

Eelmärkusena osutaksin ühele olulisele seigale. Kui meie muud uskumused ja tavad on kui mitte tervenisti, siis valdavas osas talupoeglikud, külaühiskonna kombed, siis igapäevatavades on rohkesti uudset, linnalikku ja seega 
rahvusvahelist ainest, mis on tuntud paljudes maades ja erinevatel rahvastel. Nende algse päritolu selgitamine on vaevaline, kui üldse võimalik. Meile on nad tulnud enamasti baltisakslaste vahendusel.

\section{2.}

Kombed teele minnes ja teed käies. Üldiselt tuttav uskumus, mis lähtub hirmust "ära sõnamise" ees, keelab enne teed kiitmast. "Teele minnes ei tohtinud kiita teed ega heinale minnes ilma" (Kose). Uskumus on tuntud üle maa, ehkki üleskirjutusi on hõredalt. Vististi ida poolt pärineb tava, enne teele minekut natuke istuda ja pärast tõusmist kohe minna, et käimine hästi edeneks (Halliste, Paistu, Räpina). Väheseid teateid on uskumusest, et pikemaks ajaks lahkudes - sõtta, reisile jne. - ei anna lahkuja omastele kätt, see olevat kinnituseks peatsest (elu ja tervisega) tagasipöördumisest.

Üle maa on tuntud uskumus: kui teelt tagasi pöördud millegi unustamise pärast - siis ootab teel halb õnn (Iisaku), äpardub teekäik (Muhu), tähendab üldse halba (Jüri). Ka komistamine teele minnes ennustab halba (Tallinn, Harjumaa). Mõnes teates täpsustatakse: parema jalaga komistamine tähendab tüli ja riidu, vasaku jalaga komistamine tähendab tutvumist vastassugupoole esindajaga (Tõstamaa).

Üle maa on tuntud tava, et ilma rahata ei tohi kodunt välja minna, olgu selleks rahaks kasvõi kõige väiksem münt. Kes ilma rahata kodust välja läheb, selle peale tõstab vastutulev koer jalga.

Väga oluliseks teekäigu õnnestumisele peetakse esimest vastutulijat. Naisterahvas esimese vastutulijana ennustab halba. "Kui vana naine, eriti aga vanatüdruk esimesena vastu tuleb, siis tähendab see õnnetust" (Rakvere). Uskumus on tuntud üle kogu Eesti. Eriti hullusti mõjub naisterahvas jahi- või kalamehele: "Kui jahile minnes esimene vastutulija naisterahvas oli, siis oli ükskõik, kas pööra otse ümber või mine edasi - ega saaki polnud mingisugust" (Reigi) või "Kui kalale minnakse ja tee pääl naisterahvas vastu tuleb, siis pööratakse tagasi, et kalapüük rikutud on" (Viru-Nigula). Muidugi oli "nõkse", kuidas vastutulija halba mõju neutraliseerida. Nii pidi vanast naisest vasemalt poolt mööda minema, et ta sinu õnne ära ei riku (Otepää). Laialt oli levinud järgmine uskumus: "Tööle või teele minnes oli soovitav vastutulijaskond paremuse järjestuses: mees hobuse ja vankriga, mees komps kaenlas, mitu meest vankril, naine kompsuga ja kõige hullem - naine kompsuta, siis kasvõi jäta minemata" (Torma). Ridalast märgitakse: "Tütarlaps, jänes, orav, lammas ja kõik, kes vagased päält näha, tähendavad santi õnne. Aga meesterahvas, kass, hunt, rebane, koer ja kõik, kes tigedamad loomad on, tähendavad head onnne". 
Eelnevale lähedane on teade Keilast: "Orav, hunt, rebane ja jänes ei ole head vastutulijad teel. Tuleb neist üks sulle vastu, siis on sul ikka äpardust. Head vastutulijad on ilves, karu, põder, hirv ning kits. Nendelt on head loota". Paraku ei ilmne sellest teatest kuidagi, mis on sellise jaotamise aluseks. Nii ühes kui teises rühmas on kõrvuti kiskjad ja taimetoidulised. Ka suurus ei mängi rolli, sest hunt on ju suurem kui ilves. Hoopis omapärasem on teade Tarvastust: "Kui reisile lähed, siis vaadaku, kes esimene tee pääl vastu tuleb. On vastutuleja vana naene - siis on halb õnn; tuleb noor poiss vastu - siis on imeline hää õnn. Tuleb aga elajas ehk veel isegi siga vastu, siis ära halvemat enam looda ehk parem jää seekord koju”. Kõige halvemaks peetakse siin siis veist ja siga. Seevastu Karjast teatatakse: "Kui pikemale teekonnale minnes tuleb sulle kõige enne vastu vana naine või vihamees - on teekond õnnetu; kui on esimene vastutuleja hää tuttav, sõber, meesterahvas, hobune, siga jne. - on reis õnnelik.”

Seega võime nentida, et vastu tuleva looma seostamine õnne või õnnetusega näikse olevat juhuslik. Ei ilmne ka mingisuguseid eelistusi geograafilisel tasandil, s.o. kihelkonniti. Vastavaid teateid on ka küllalt vähe. Võib-olla saaks usutavamaid teateid, kui uurida iga looma eraldi kõigist aspektidest - mitte ainult vastutulijana. See eeldaks aga hoopis rohkem aega, kui ülevaate koostajal kasutada oli. Leppigem siis sellega, et vastu tuleva inimese suhtes on seisukohad ühesugused üle maa. Võrdluseks märkigem, et naine (eriti vana naine) oli ka ebasoovitav esimese külalisena uuel aastal.

Halba ennustas ka see, kui esimene vastutulija rannaäärsetes kihelkondades oli mundris, s.o. kroonuametnik. Eriti kardeti halba merevahist, s.o. piirivalvurist. Ju olid piirivalvuri kohustused sedavõrd vastuolus rannarahva mentaliteedi ja eluharjumustega, et sinna ei mõjunud ka sisemaal levinud uskumused, mis nägid kroonumundris mehes õnnetoovat vastutulijat.

Juba käesoleval sajandil on hea-halva vastutulija eristamine üldistunud. Linnades (eeskätt Tartus ja Tallinnas) ja peamiselt koolilaste hulgas valitseb uskumus: "Kui majast välja lähed, kui esimesena noor inimene vastu tuleb - on hea õnn; aga kui vana inimene vastu tuleb - on paha õnn" (Tallinn). Aga maal jääb valitsema uskumus: "Kellel hommikul isane vastu tuleb, sellel on hea õnn; tuleb aga emane vastu - siis on tal õnnetust" (Kaarma). Pärnust pärineb teade: "Hää tähendusega on, kui kooliteel tuleb esimesena vastu meesterahvas, mida noorem, seda parem."

Meie linnade olmet kajastavad üsna hästi kooliõpilaste uskumused: "Kui kooliteel tuleb vastu heinakoorem - läheb hästi, õlekoorem - halvasti" ja "Kui tuleb vastu puu- või õlekoorem - läheb eeloleval päeval halvasti” (Pärnu). Halba ennustab ka see, kui õpilastele tuleb vastu sant, vene papp, must kass, vana naine; seevastu sibi ja korstnapühkija ennustavad head. Rõhutagem, et nimetatud tegelased ei pruugi olla esimesed vastutulijad. Kohtumine nendega 
tähendab igal juhul vastavalt head või halba. Eriti usuti korstnapühkijate õnnetooja võimesse. Laialt on levinud uskumus: kui näed korstnapühkijat, siis võta mustast asjast kinni ja soovi midagi, musta asja võid lahti lasta alles siis, kui kohtad või näed kroonumundris meest. Viimaseid näeb tänapäeval alatasa, kuid korstnapühkija on haruldaseks muutunud. Usk korstnapühkija õnnetoovasse mõjusse on aastatega isegi kasvanud ja on tänapäeval üks levinumaid kujutelmi. Muidugi on õnne "ülekandmiseks" vaja korstnapühkijat puudutada (parema käe nimetissõrmega), kiskuda ta kuuelt üks nööp või murda harjast üks oksake. Praeguse traatharja puhul on see enamasti võimatu. Niisiis leppigem puudutusega seegi toob õnne, konkreetsemalt - hea eksamihinde.

Üle Eesti on tuntud uskumus: "Kui tuttav inimene tuleb teisele vastu ja see ei tunne teda ära, siis vastutuleja pidi raha saama”. Seegi on rahvusvahelise päritoluga ja levinud peamiselt linnades.

Teekäija pidi jälgima sedagi, kes ja kuidas tema teest üle läheb. Kui teest minnakse üle vasakult paremale - siis see tähendas head. Mindi aga paremalt vasemale - siis see tähendas halba. See kehtis nii inimese kui ka looma kohta. Varem arvati seda ka kassist. Sajandivahetusel aga levis uskumus, et teed ületav kass - eriti veel must kass - tähendab igal juhul onnnetust. Huvitav on täheldada, kes kõik võisid teed ületada: kass, koer, jänes, orav, rebane, madu, metsloom, üldse loom. Tänapäeval peame mõistagi leppima ainult kassi, koera ja inimesega. Teistega (jänes, rebane jne.) kohtumine on juba enam kui haruldane.

Kui teekäija möödus töötegijatest, siis enesestmõistetavalt soovis ta jõudu (s.o. jõudu tööle). Kui seda ei tehtud, siis hõikasid töötajad: "Kas krapiga emist oled näind?” või kui mööduja oli mees "Kas krapiga hunti oled näind?". Jõudu soovimisele oli vastuseks "Jõudu tarvis!".

Vastutulijat tervitati. Kui tervitusele vastati, oli hea. Kui aga vastutulija kõrvale vaatas - tähendas see halba. Kui vastu tuli jahi- või kalamees, siis ei tohtinud talle iialgi "head jahiõnne" resp. "head kalaõnne" soovida. Seesuguse sooviga sõnuti jahi- või kalaretk ära. Sooviti "Kivi kotti!".

Väga levinud ja jällegi uueaegne on uskumus, et kui kaks inimest koos kõnnivad, siis ei tohi nad teine teiselt poolt puud ega posti minna. Kui nad seda siiski teevad, siis tuleb nende vahele tüli ja pahandust. Pahandust, tüli ja riidu tuleb ka siis, kui mööduja või vastutulija läheb kahe kõndija vahelt läbi.

Vastutulija möödub sinust pahemalt poolt - see on vana pruuk. Usuti, et paremalt poolt möödumine viib õnne ära (Kuusalu). Hiljem on täpsustatud: paremalt poolt ei tohi mööduda meesterahvas naisterahvast (Torma), ei tohi mööduda vana naine (Otepää), korstnapühkija (Tallinn), ei tohi mööduda siis, kui kalale lähed (Tartu-Maarja). 
Ammune ja kindel tava oli värava (aia-, kopli-, karjamaa-, metsa-jne. värava) või aiamulgu läbimisel see taas sulgeda. Usuti, et see, kes värava lahti jätab, ei saa enam rahulikult magada või näeb tihti halba und.

Majja (apteeki, poodi jne.) sisenemisel tuli eesõigus anda väljujatele. Tänapäeval, kus enamikus avalikes asutustes - hoolimata projekteeritud ja ka ehitatud uste arvust - on avatud ainult üks uks (eelistavalt sellestki vaid pool), tuleks see vana pruuk uuesti ellu äratada, et vältida tarbetuid rüselusi.

Kõik need uskumused ja tavad kõnelevad kaasinimese arvestamisest. Inimene ei olnud üksi. Ta oli ümbruskonnaga tihedalt seotud ja see mõjutas temagi samme ühes või teises suunas. Kõiki tuli arvestada, kõike tuli ette näha ja kõigel oli ka seletus.

\section{3.}

Kombed külla minnes ja külas olles. Tuleb arvestada, et siin on tavad kahepoolsed: ühelt poolt need, mis kõnelevad külaliste sündsast või ebasündsast käitumisest, teiselt poolt need, mis reeglistavad võõrustajate käitumist. Need ei olnud päris kattuvad.

Vanasti ei läinud ükski naisterahvas külasse või teise talusse ilma kostita. Kui muud polnud viia, siis kasvõi kannikas külaleiba. Kui küllaminek oli aegsasti teada või ettekavatsetud, siis valmistati ka spetsiaalne "külaleib" (Mulgimaal sageli korp, Kagu-Eestis linnasejahust leib, üldse midagi paremat). Kohati on olnud tavaks, et kostiks viidi terve asi (s.o. terve leivapäts, mitte poolik).

Külaskäigu nurjumist või halba õnne ennustas see, kui külla minemisel “jalg valla lääb”, s.t. kui pastla-, kinga- või saapapael katkeb või sõlmest lahti läheb.

Üle Eesti levinud on ended külalise ootusest: kui söömise juures kukub nuga maha, siis tuleb - samal päeval - meeskülaline, kui kahvel - siis naiskülaline. Ka lusika kukkumine ennustab naiskülalist (Rapla). Kohati valitseb arvamus: kui päise päeva ajal uni peale tikub, siis on külaline tulemas (Pärnu-Jaagupi). Sedagi uskumust on veelgi diferentseeritud: unine olek ennustavat laiska külalist (Tartu-Maarja) või rikast külalist (Maarja-Magdaleena). Külalist ennustas ka see, kui küdevast ahjust viskas sädemeid tuppa. Mitmelt poolt on teateid sellest, et kui kauss laual liigub, tuleb külalisi. Külalise tulekut ennustas ka kass, kui ta käpaga silmi pesi. Kohati on sedagi ennustust varieeritud: "Kui kass koukas käbäga oige kaugald kukla tagand - tuleb oige kaugald vieras kohe. Pesi aga kass külillä olless oma silmi - oige laisk vieras on tulemas" (Kuusalu).

Huvitav teade on Ristilt: "Pühade aegas ei tohi enne kuskile külase minna, kui kukk on laulnd. Lapsed käisid siis kukke torkimas". Üldine, kuid suhteliselt hiline on tava esimesel jõulupühal mitte külas käia. Külastamiseks olid teine ja kolmas püha. Teiste pühade puhul sellist üldist külastamiskeeldu ei 
teata, kuigi kohati on nimetatud tähtpäevi (näit. paastumaarjapäev jt.), millal külas ei käidud.

Hoolikalt jälgiti ka külastamisaega. Arvati, et õhtune külaline toob õnne, hommikune külaline aga õnnetust. Teisalt valitses arvamus, et naisterahvast külaline nädala alguses viib töölt jõu ja edenemise, meesterahvast külaline aga annab tööle jõudu. Sama arvamus seostatakse asja otsimise või laenamisega nädala alguses - see on halvaendeline; kui aga midagi tuuakse - ikka nädala algul - siis see on heaendeline märk.

Üldine nõue oli, et kui lähed võõrasse õue, ei tohi ka vitsaraagu võtta. Võõras on võõra oma. Ka ei soovitatud söögi ajaks külla minna - sealsed koerad hakkavad külalist vihkama. Majja minnes ei tohi lävele astuda, peab astuma üle läve. Lävele astumine toob majja tüli ja riidu. Hulgakesi minnes läheb mees enne tuppa - see toob majale õnne. Kui naisterahvas enne tuppa läheb ja mees järel - see toob peresse õnnetust.

Laialdaselt levinud, ent tänapäeval juba kõnekäänuks muutunud tava on haruldase võõra puhul rist seina peale teha ("Kuhu see rist küll teha!") või võõras üles tõsta.

Külaline oli arvestatav mitmestki eri aspektist. Kui külamees (noormees!) tuleb ja istub lõukale, siis saavat sellest väimees (koduväi). Kui külaline tuleb majja siis, kui kangast on alustatud - olevat tal pikk iga. Kes tuleb külla siis, kui kangas on lõpetamisel - sel on lühike iga. Nii kinnitavad teated Simunast, Emmastest, Vändrast, Kolga- Jaanist. Kui uue alustatud ehituse - laut, ait, tare - juurde tuleb esimesena rase naine, siis on see ehitusele väga hea enne (ehitus valmib ruttu, peab kaua vastu jne.). Kui võõras satub majja siis, kui perenaine süüa teeb, peab perenaine enne teretamist põllega käed puhtaks pühkima siis ei vii võõras söögi tulu ära. Võõrale tuleb süüa pakkuda - see tava on tuntud üle maa. Kuid ei olnud viisakas lasta võõral üksi süüa. Siin on tavas kihelkonniti hulk variatsioone. Mõnel pool pidi peremees võõraga lauda istuma - see toovat lambaõnne. Teisal istus perenaine võõraga lauda - see tõi karjaõnne (Rapla, Vändra), kaksikud talled (Vändra), pikad linad (Rõngu, Otepää, Sangaste, Vastseliina). Kui võõras söömata lahkub, võtvat ta pereõnne kaasa (Haljala, Palamuse, Kursi). Muidugi pidi võõras enne lauda istuma kui oma pere, iseäranis lapsed. Teisalt valitses tava, et külalisele ei tohi teist korda süüa anda - siis viib ta söögi tulu ära.

Külaline aga arvestagu seda, kui ta söögi ajal tuppa astub, ei tohi ta sealt enne ära minna, kuni pere on söönud ja toit laualt koristatud - muidu viib ta selle maja leivajätku kaasa. Sellegi vastu oli oma "kunts" - kui võõras söögi ajal tuppa tuli, nihutati pinki (või toole) ja lauda - et leivajätk kaotsi ei läheks. Viimane tava on tuntud laial alal Kesk- ja Lääne-Eestis. 
Muidugi soovib viisakas võõras söögiajal peresse sattudes "Jätku leivale!" või "Jätka (jumal) leiba!" Kahest soovist on tänapäevaks kujunenud üks "Jätku leiba!" Teadmisel, et tallegi süüa pakutakse, lisab ta naljatamisi "Minu leivaisa ikka elab veel!" Talle vastatakse "Jätku tarvis!" Ja kui külaline ise ei vihja oma leivaisale, siis öeldakse ka "Näe, sinu leiva isa elab veel!". Iisakust on tava kohta järgmine seletus: "Kui keski süema ajal juhtub tulema, siis arvatakse, et sellel leiva puudu ei saa olema ja üeldasse: "Sinu leivaisa elab!". Ehk tulija ütleb: "Jumal tänatud, minu leivaisa ikke elab!". Tava on tuntud eriti Põhja-Eestis.

Kui külalist sööma kutsutakse, ei ole kombeks kohe esimesele kutsele reageerida. Aga viisakas ei ole ka kaua vastu puigelda. Sööma peab - muidu viib külaline lambaõnne ära, lambad ei sigi ega kasva. Kui perenaine külalist ühtelugu süüa käsib, vastatakse: "Ega söömal kubjast ole!". Mõnel pool oli tavaks, et võõras ei võta enne liha, kui kästakse (Räpina). Sööma pidi, kuid mitte ülemäära - kes üheksa korda sõi (s.o. üheksa korda ette tõstis), see pidi pere leivajätku ära viima.

Teisalt valitses uskumus, et külalise toodud kost tuli kiiresti ära maitsta muidu läheb kosti tooja vanaks. Külalist ei tohtinud tuppa üksi jätta. Külaline taas ei tohtinud kõike, mis näha-kuulda, ülemäära kiita. Seda pandi pahaks, kuna ülemäärane kiitmine pidi kiidetu ära sõnama (peatab kasvu, edenemise, toob õnnetust jne.). "Ära" kiitmise vastu aitas mõnikord üle õla sülitamine (kolm korda), vastu puud koputamine (kolm korda) ja ka kiitja sõimamine või halba kohta saatmine, ka mõttes. Näiteks võõrale, kes sattus võitegemisele ja värsket võid kiitis, sooviti lausa "Sitta suhu!". Niisiis tuli võõrsil olla tagasihoidlik ja tasakaalukas, tuli vältida emotsioone mõlemas suunas - nii negatiivseid kui positiivseid.

Valitses uskumus, et kui keegi võõras majas aevastab - siis oodatakse teda (aevastajat) koju. Kaasajani ulatub uskumus, et külas olles ei tohi jalgu teineteise peale risti panna! Kui seda tehakse, siis lõpeb jutt otsa. Tekkinud vaikuses küsitakse nüüdki: "Kelle jalad on risti?". Tänapäevane on seegi uskumus, et vaikusehetk seltskonnas tekib 20 minutit enne või pärast täistundi (seda on hõlbus kontrollida!). Vähe saksikumad või saksa kultuuri mõjualused kviteerivad seesugust vaikusehetke ka lausega "Ingel lendas läbi toa".

Enne külast lahkumist - s.o. kui oli juba tõustud lahkumiseks - pidi veel tingimata hetkeks istuma (et kodutee läheks hästi, et jõuaks ilusti koju, et läheks hästi). Lahkumisel ei tohi jumalagajätuks kätt anda üle läve, see toob kaasa riiu. Seevastu ei leita erilist tähendust kätlemisel siin- või sealpool läve. Juba ununemas või ununenudki on tava lahkuvat külalist mõnda aega saata (et lahkuja ei viiks ära tööjõu, une, lambaõnne, et saata lahkujaga laiskus ühes, et lahkuja laiskust maha ei jätaks). 
Teadaolevalt või ka oletatavalt pahasoovliku võõra halbatoova mõju kaotamiseks või ka vähendamiseks oli mitmesuguseid võtteid. Üks levinumaid oli kuiva tuha jalajälgedesse riputamine. Samuti visati kolm korda tuhka järele (et võõra kuri silm loomadele ei mõjuks), või visati üks kord tulist tuhka. Levinud oli ka soola järele viskamine (et see võõra soovid-sajatused tühjaks teeks). Mõnel pool oli kombeks igale "tahtmata külalisele" tuhka järele visata, n.-ö. kindluse pärast.

Need tavad näitavad küllalt selgesti, et nn. külaskäigud olid muiste kas väga haruldased või koguni tundmatud. Võõrsil käidi kas asja pärast või kutsel (aga eks kutsegi olnud teatavaks konkreetseks puhuks - varrudeks, pulmadeks, peiedeks). Muide, sünnipäeva pidamine on eestlastel üpriski noor tava. Möödunud sajandist peaaegu polegi teateid sünnipäevade pidamisest. Näib küll, et alles nõukogude võimu aastatel on sünnipäevade pidamine muutunud ülemaaliselt tuntud ja harrastatud tavaks (võimalik, et tasakaalustada riiklike pühade vähesust ja hallust). Viimasel ajal ongi sünnipäevad kujunenud kõige olulisemaks isikliku eluga seotud pidustuseks, mis varjutavad isegi muud, põliselt vanad tähtpäevad nagu varrud ja peied. Pulmad veel võistlevad sünnipäevadega - sest nagu ütles üks kümneaastane nooruk õe pulmade kohta: "Palju siis inimese elus neid pulmi on! 3-4, mitte rohkem!"

\section{4.}

Kombed söögi tegemisel, söömisel ja laua koristamisel. Kõigepealt märkigem, et toiduainete säilitamise nõud olid muiste esmased ilmaennustajad. Sellest on rohkesti teateid. Nii märgitakse Jämajalt: "Kui liha- või kalanõud on väljastpoolt märjad, on varsti oodata vihma või vähemalt ilmade muutust". Muidugi oli tegu puunõudega. Jürist teatatakse: "Hea ilmade ette kuulutaja on kapsaasti, kui ta talvel toas on, kus ta ei külmeta. Kui kapsad kuivaks tõmmavad, siis tuleb külma ja kuiva. Tuleb aga vesi peale siis tuleb sadu". Sula (või sadu) ennustab ka see, kui seebid (lahtilõikamata seebikäiad) ja soolanõud märjaks löövad. Harvad teated (ent üle maa) kinnitavad: kui laud supikausi all märjaks jääb - siis tuleb teisel päeval sula või sadu. Kui räime- või heeringapütt läheb ligedaks e. hakkab higistama - siis on oodata suurt sadu.

Muide, kaasajani ulatub arvamus (kui tõsine veel, kes seda teab), et siis tuleb ilus ilm, kui laual kõik nõud tühjaks süüakse (s.o. kui lõunaks, eineks jm. valmistatud toitu järgi ei jää). Kui aga põhja peale jääb piisake (et ei jätku järgmiseks söömaajaks) - siis hakkab vihma sadama.

Rohkesti oli uskumusi ja endeid seotud sööginõudega. Suhteliselt uueaegne ja rahvusvaheline - millal need klaasnõud taluperesse tulid! - on uskumus, et 
klaasnõu purunemine toob õnne. Seda väljendab üle maa levinud vanasõna: "Killud toovad õnne!" Muidugi kantakse see üle ka savi-, fajanss- ja portselannõudele - ehkki vanemad teated räägivad just klaasnõust (ja savinõu oli tuntud ju ammu enne kui klaas). Muide, purunenud peegel ja selle killud ei too õnne. Vastupidi - purunenud peegel tähendab õnnetust, enamasti suurt ja tõsist õnnetust, mitte tühist äpardust. Tõsi, seegi uskumus on rahvusvaheline ja meil küllaltki hiline (millal need peeglidki talutarre jõudsid!).

Endelise iseloomuga on teade: kui pann roostetab - sureb perenaine. Muidugi on see tõlgendatav ka nii, et panni hooletusse jätmisel on perenaine juba nii vana või haige, et surm pole enam kaugel. Taolisi teateid pole palju. Hoopis laiemalt on tuntud ended, mis on seotud paja või katla vingumise või kiunumisega. Enamasti ennustab see perenaise surma (Vaivara, Viljandi, Tõstamaa).

Sageli märgitakse metafoorselt - jääb vaeslapsi (Türi, Halliste, Tarvastu, Äksi, Laiuse, Võnnu, Häädemeeste, Käina). On ka teateid, milles viidatakse surmale peres, mitte konkreetselt perenaisele (Anseküla, Laiuse, Tartu- Maarja). Siingi on mõnikord kasutatud metafoori: undav pada tähendab, et sellega keedetakse peiesööki (Otepää), et sellega soojendatakse surnupesuvett (Juuru). On ka mahendatud endeid: kui pada, katel või muu keeduriist vilistab, siis keegi lahkub majast. Ent on ka teateid:kui pada tulel või keemisel kiunub, siis tulevad kaugelt või näljased külalised (Suure-Jaani, Põlva).

Mõistagi ei võinud tühja pada tulele panna - pada võis lõhkeda. Et see keeld meeles püsiks, seoti see rahvasuus hoiatusega: kui paja tühjalt tulele paned, siis jäävad lehmad ahtraks.

Tule eest pidi hoolitsema üks inimene. Siingi on käibel hoiatus: kui ühe paja all kaks inimest tuld koristavad, siis lähevad nad varsti riidu.

Laialt levinud - praktiliselt üle Eesti - oli uskumus: kui pada keskelt enne keema hakkab kui äärest, siis tulevad võõrad (võõras, külainimene).

Kõik tehtav tuli teha hoolikalt. Räpakus ja hooletus olid taunitavad. Sellele viitab näiteks teade Kaarmast: kui võtsid paja tulelt nii, et kook jäi õõtsuma (niisiis räpakalt), siis langes see inimene teiste tagarääkimise alla (s.o. sattus kuulujuttude ohvriks).

Igal asjal oli oma otstarve. Nii ei tohtinud pajaga vett tuua - jõest kaovad kalad või kaevuvesi läheb sandiks. Kes katlas riistu peseb, sellel jääb eluks ajaks tilk nina otsa. Pajast ei tohtinud ka süüa - tulevad mustad lapsed (mõeldud muidugi kasimatust, mitte ihuvärvi). See uskumus on laialt levinud üle kogu Eesti.

Uuem uskumus on, et kohvikannu ja praepanni ei tohi ilmaski pesta - õige maitse minevat kaduma. Teateid on sellest küll hõredalt.

Kui puder üle poti keeb - see on perenaise hooletus - siis tähendas see kas õnnetust, üldse halba või vihmast sõnnikuveoaega. 
Söögilaud oli püha. Selle peal söödi, ei muud. Alles hilisemal ajal on tulnud tavaks söögilaual muudki teha: lugeda, kirjutada, teha käsitööd jne. Muiste oli söögilaud ainult söömiseks. Muidugi ei tohtinud söögilaual istuda. See oli nii suur eksimus, et sellele ei leitud karistustki.

Söögiks ei tohtinud rohkem lusikaid lauale panna kui oli sööjaid, sest "prii lusikad söövad nasamma kui oleks tal sööja taga”, nälg tuleb majasse, tont sööb ühes, hukatud tüdrukulaps sööb ühes. Suppi ei tohi valada ega tõsta üle paja sanga - sööjal hakkab kõht valutama. Ühe söömaaja jooksul ei tohi kahe lusikaga süüa - kõht ei saa täis, lapsed sünnivad suure suuga. Hea tava oli kogu valmistatud toit ära süüa. Peale muu ennustas see järgmiseks päevaks ilusat ilma.

Abielunaine ei tohtinud süüa katmata peaga. Kui ei olnud tanu, siis pidi olema rätt. Tüdrukud muidugi olid katmata peaga. Ja mehed pidid söögiajaks mütsid maha võtma - nii tanu naise peas kui mütsita mees olid mõlemad toidu austamiseks. Saadi ju igapäevast leiba ainult väsimata tööga. Leiba austades austati ka iseennast.

Laua ääres istuti rahulikult. Juhtus - enamasti laps - jalgu kõigutama, järgnes peagi vanaema või vanaisa repliik: "Mis sa vanajuuda last hällitad?" Mõistagi ei tohtinud söögiajal naerda. "Kes sööma ajal naerab, see sööb hobuse sitta” (Keila). Söögiajal ei tohtinud olla tõusmist-istumist, sisse- ja väljakäimist. Liikus ainult toidutooja. Ilmaaegu käimine tõi toidule kadu - võttis söögilt jõu ära. Söögiajal ei räägitud paha ega ka virgutatud vastamisi sööma - kes seda teeb, see kaotab kõhutäie. Kui keegi seisab sööja taga, siis tuleb sööja kõhutäis seisjasse. Kui oled söönud, ei tohi istet jätta laua äärde - kõhutäis jääb ka laua äärde. Söögiajal ei tohi toast lahkuda - see viib majast söögijätku. Last ei lasta minna, kui vanemat inimest peatada ei saa, tuleb söögilauda kolm korda nihutada.

Söök oli muistegi vabalt võtta. Ainult leiba lõikas peremees igale pereliikmele vastava tüki. See algsest leivanappusest ajendatud komme püsis kaua, ka siis kui kartulikasvatamise laienemine päästis eestlased kroonilisest alatoitumisest, kohati isegi veel kahekümnendal sajandil.

Siit ka tuntud paljude variantidega naljand peremehest, kes lubab sulasele söömaks seesuguse leivatüki, mida kahe käega tõsta saab. Sulane mõtleb, et leivatükk on nii suur - aga tegelikult lõigati nii õhuke viil, et seda ei saanud ühe käega tõsta - laguneb ära. Kuivõrd naljand on populaarne, pidi ka selle aluseks olev tava teada ja tuntud olema. Samuti lõigati liha igale tükk. Palju söödi oa-ja hernesuppi. Nende juurde leiba ei võetud - oal-hernel on leib põues (või leivapäts kõhus). Mõistagi ei söödud leiba tangu- või kruubipudruga. "Kes pudru juurde leiba sööb, see läheb vangi” või saadetakse Siberi (Kuusalu). Säästlik suhtumine leivasse ilmnes ka nüüdseks juba ununud tavas - maha- 
kukkunud leivatükile anti suud. Leib oli peaaegu püha. Leiva üle ei virisetud ega nurisetud. Temasse suhtuti austavalt - oli ta milline oli. Leivaga mängimine või leiva loopimine oli midagi kuulmatut, enneolematut, nii suur patt, et sellele ei leitud otsest ja ainulist karistustki. Leivasse hoolimatult suhtujat ähvardas nälg, onnnetused peres, raha puudumine ka pärast surma. On teateid, et hooletu või pahatahtlik leivapudistaja peab pärast surma kõik mahapudistatud leivakübemed üles korjama - enne kui rahu leiab.

Laialt on levinud uskumus, et näljane külaline tuleb siis, kui suutäiest midagi lauale, rüppe või maha kukub. Kohati on see segunenud söögiriistade kukkumisega. Nii teatatakse Muhust: "Kui söögiajal nuga või leivatükk laua alla kukub, siis öeldakse, et näljane tuleb”. Mõnikord on uskumust veelgi diferentseeritud: "Kui esimene suutäis suhu pistes maha kukub, tuleb näljane külaline" (Saarde) või "Kui külalisele süüa lauale viies mõni asi käest kogemata peaks maha kukkuma - kas leib, nuga või kahvel - siis üteldakse, et sellel päeval saada veel mõni külaline tulema" (Halliste) või "Kui kellegil süües leivatükk suust maha kukkunud, siis arvatud, et näljane külaline võersiks tuleb" (Vigala).

Söögiajal ja ka pärast sööki ei tohi jätta lusikat kausi, paja, taldriku ääre peale - siis söövat lusikas omajagu edasi ja toit ei õnnista. Lusikas tuli panna lauale (ja kummuli - kahasüvend allapoole). Tühjaks söödud nõule tuleb kohe kaas peale panna - perenaine või toidutegija suu seisvat seni lahti, kuni kaas peale pandud; kes jätab kaane panemata, sellel jäävad pärast surma silmad lahti. Ka õllekannukaas tuleb kohe peale joomist sulgeda (vanad puukannud olid valdavalt kaanega) - kui ei, siis jäävad selle jooja hambad pärast surma irevile.

Sööginõusid ei tohi ilma nuustikuta (s.o. palja käega) pesta - muidu tuleb tühi majasse. Peale pesemist tuleb söögiriistad kuivatada. Kui söögiriistad jäetakse kuivama (meie nn. Laisk-Liisu!) - siis tulevad majja õnnetused ja nälg.

Kui pada on tühjaks söödud (resp. toit pajast ära tõstetud), tuleb see kiiresti puhtaks pesta. Kes paja pesemisega viivitab, sellel saavad tatised lapsed olema või lambad ei laku vastsündinud tallesid (s.o. ei võta omaks). Pada uhutakse ülevalt alla - siis ei kee ta üle. Ka pajasang tuleb ära pesta. Kes pajasanga pesemata jätab, selle laste ninad on alatasa tatised või toidujätk võetakse ära. Ent pajasangal on ilmselt suuremaid ja metafoorsemaid funktsioone nimelt on üllatav n.-ö. mütoloogiliste karistuste ohtrus, mis ähvardab seda, kes jätab pajasanga pesemata: vanatont kuseb patta, vanapagan hävitab kõik naisterahvad, kurat pääseb põrgust, kurivaim võtab ära leivajätku. Ja kõige huvitavam: kes peseb pajasanga - see kinnitab põrgus kuradi ahelaid (vrd. seppade vasaralööke alasile, mis samuti kinnitavad kuradi ahelaid). Ootamatu on ka teade: kui üle pajasanga kolm korda vett visata, siis tulevad kodukäijad! Ilmselt on pada koos sangaga millegi olulise võrdkuju, sümbol (kas taevakuppel vikerkaarega?). 
Pada peab küll pesema, kuid mitte kaapima. Kes pada kaabib, sellele tulevad musta peaga lapsed. Ja pesta tuleb ka paja pesemise nuustikut. Kui pesunuustik loputamata ja väljaväänamata jääb - siis tulevad taas lapsed tatise ninaga.

Pärast söömist tuli laud kiiresti koristada. Kui nõud ja söök lastakse kaua laua peal olla, siis on peaaegu üle Eesti ettenähtud ühesugune karistus - poja (või tütre) pulmalised e. pulmad jäävad seisma. Mida kauem pulmalised ühes peres on, seda enam nad söövad-joovad, seda suuremad on kulud. Muidugi varieerub seegi ähvardus: tulevad näljased kosilased (Haljala), kosilased ei lähe ära (Tarvastu), saajad külmavad suure soo pääle (Rõngu), pulmas jäävad võõrad öömajale (Kaarma), pulmarahvas sööb vaeseks (Tartu-Maarja), süüakse pulmades kõik ära, ka taariraba (Viljandi), tüdrukud ei saa mehele (Kambja). Huvitav teade on Põlvast: "Ku tütrek pikkamiisi laua päält sööki kasib, sellel laskvad peigmehe ima kaua ilma tanota sajaaigoja aigo laua takah istu".

Üksik teade väidab: "Õhtusööki ei tohi laualt ära korjata, vaid tuleb lauale jätta, siis ei tulla vaesus majja”. See on küll tavaks jõuluõhtul ja vana-aasta õhtul, mitte aga argipäeval.

Pärast sööginõude koristamist tuli laud ka ära pühkida. Kui perenaine jätab laua pühkimata, siis jätavad lambad vastsündinud talled lakkumata või sünnivad kirjud talled. Ka laua pühkimiseks on kindlad tavad. Lauda ei tule pühkida risti - siis tuleb majasse leivapuudus või kaob toidujätk. Lauda tuleb pühkida pikuti ja ühte nurka kokku ning külje pealt maha (mitte otsast) - siis ei tule majja leivapuudust (ei jää maja vaeseks, leivaõnn ei lähe ära). Saaremaal on tava lauda pühkida oma poole, siis seisab tulu käes. Kui pühid väljapoole, siis pühid leiva laua pealt ära. Mandril on tavaks, et lauda ei pühita ukse poole, vaid ikka seina poole - et ei tule toidupuudust. Üle maa on tuttav tava: lauda ei tohi pühkida peoga ehk palja käega - siis tuleb vaesus majja, tuleb leivapuudus, ei ole leivaõnne, põld läheb järgmisel aastal hukka, nälg tuleb majja, laud jääb paljaks (s.o. tühjaks). Vastseliinas öeldakse kujukalt: "Kes söögilauda palja käega pühk, see saap ka esi paljas jääma kui tühi laud ja paljas peo!” või veel markantsemalt: "Pühku 'õi lauda palja käega - kodapoolitses jäät" (kodapooline tähendab popsi, ilma kindla koduta inimest).

Ka paberiga ei tohtinud söögilauda pühkida. See toob tüli ja riiu majasse. Seegi tava on tuntud üle maa.

Siingi varieerub hoiatus: perekond läheb lahku (Laiuse), peresse tuleb kadedus (Märjamaa), majarahvas jääb vaeseks (Narva), nälg tuleb majja (Torma), pühitakse leivajätk välja. Lauda ei tohi pühkida ka põllega - samal päeval tulla suur pahandus või palju tühja juttu. Ka õlgedega (õlenuustakuga) ei tohi lauda pühkida - pere kuivab ära või rukis kasvab kasteheinane või songivad sead rukkiorase ära. Kui söögilauda villase riidega pühkida, siis põlgavad lambad pojad ära. Niisiis tuleb söögilauda pühkida linase lapiga. Enamasti on tegu 
spetsiaalse laua pühkimise lapiga, sest manitsetakse: laua pühkimise lapiga ei tohi teist lüüa - lööja saab soolatüükad. Laua pühkimise lapiga ei tohi ka sõrmi pühkida - sõrmed hakkavad vastama (s.o. kestendama).

Kui koristamisel unustatakse lauale leivatükk, siis tuleb võõraid. Mõnel pool on uskumus diferentseeritud: kui leivatükk jääb lauale - tuleb rikas külaline, kui lusikas - siis vaene külaline. Lauale unustatud lusikas ennustab ikka kas lihtsalt külalist või näljast külalist. Ometi on Tapalt ka vastupidine teade: kes lusika lauale unustas, see läheb külasse. On ka üldistatum enne: kui lusikas lauale juhtub jääma, on keegi söömata (perest, suguseltsist).

Laua koristamine oli enamasti tüdrukute töö (perenaine kattis laua). Tüdrukuid manitseti: kui söögilauda hooletult koristad ja pühid, siis saad pudruse suuga mehe või räpased ja tatised lapsed. Laua pesemisel ei tohi äärele tilkasid jääda - pesija saab ilase suuga lapsed ehk tatised lapsed. Lauanarts pidi olema suur - siis olla ka suur sissetulek.

Söömine oli tõsine, peaaegu pühalik toiming. See ilmneb selgesti, kui jälgida kõiki kombestikus esinevaid käske-keelde, mis seotud söömisega. Iialgi ei söödud mütsiga. Kes müts peas sööb, selle toit läheb mütsi sisse - inimene ei saa sellest midagi. Abielunaised aga pidid sööma tanu või vähemalt pearätt peas. Samuti ei söödud ilma vööta. Sööma tuldi rahuliku meelega. Kui söögi pärast tüli tõstetakse - enne söömist - siis polla järgmisest söömisest miskit tulu, kõht jäävat tühjaks ja tegevat vaeva (Halliste). Normaalseks loeti, et pere sõi koos. "Kui inimesed, oma pere muidugi, kõik seltsis söövad ja ridastikku oma vanaduse järele istuvad ümber laua - siis on alati hää lambaõnn" (Pärnu-Jaagupi). Analoogilisi teateid on küll hõredalt, ent üle maa. Ja vastupidine teade: "Ütsinda ei tohi laua man süvvä, siis lääb koorm, mis sa viad, ümmer" (Tarvastu).

Põhja-Eestis oli hilinenud pereliikmel tavaks öelda söövatele omastele: "Näe, Roots juba rual, vana Venelane ei teagi!” Kõnekäänd on levinud, kuid tema ajend on uurimata. Ons siin vihje üllatusrünnakule Narva all Põhjasõja ajal? Või viitab kõnekäänd veel vanematele vahekordadele Liivi sõja ajal või hiljem?

Söödi koos ja ühel ajal. Kui ühed söövad ja teised töötavad, siis ei õnnestu kumbki: äpardub töö (Saarde) või kaob leivajätk (Vändra).

Tavaks oli istuda ümber laua. Laua ühel küljel ei söödud, kui teine külg oli tühi. Usuti, et neil, kes istuvad laua ühel küljel, läheb koorem ümber (tuttav Mulgimaal), või istub vanakuri vastas (Lõuna-Eesti) või lähevad nad koos hobusevargile (Otepää). Laua ots oli tavaliselt perenaisele-peremehele määratud. Mitmelt poolt on teateid, mis kõnelevad sellest: kes laua otsa istub, sellest saab peremees. Ent on ka teateid, et laua otsa istujast ei saa perenaist (Narva), et laua otsa istuja lahkub majast kõige enne (Väike-Maarja). Tänapäevani püsib tava, et neiu (ja noormees) ei tohi istuda laua nurka (eriti jälgiti, et sööja jalad 
ei jääks teine teisele poole lauajalga) - muidu jääb vanatüdrukuks (või vanapoisiks) (Türi, Ambla, Muhu, Tartu-Maarja) või peab veel seitse aastat kosilast (kositavat) ootama (Türi, Pärnu, Tõstamaa, Laiuse, Helme, Sangaste, Kanepi) või jääb abielus leseks (Palamuse). Uueaegsem ja rahvusvaheliselt tuntud on uskumus, et kolmeteistkümnendana ei tohi lauda istuda. Üldse oli hea, kui lauas istus paarisarv inimesi.

Teisalt on teateid, et lapsed ülepea ei söönud istudes. Söögilauda istumisloa sai alles noormees, kes oli kündnud kasvõi ühe vao, ja tüdruk, kes oli käinud leeris ühe päeva. Nii väideti: "Kui tüdruk süües pingi peale istub, jääb ta ruttu vanaks" (Karksi). Lastest arvati, et nende kasv jääb kinni, et saavad enneaegu vanaks, kui nad söögilauas s.o. süües istuvad. Vanadest jälle arvati, et süüa ei tohi seistes. Siis minevat söök jalgadesse ja inimesele pole söömisest mingit kasu ega tulu. Saaremaalt on rohkesti teateid: kes püstijalu sööb, sellel kasvavad jämedad sääred (Kaarma, Jämaja, Kihelkonna, Anseküla).

Hoolikalt jälgiti seda, et keegi ei sööks teise selja taga. Tava on tuntud üle maa. Kõige levinumaks põhjenduseks on: teise selja taga süües võtad tema jõu ära. Aga arvati ka, et niiviisi süüakse ära teise õnn ja kasv, et sööd teisele küüru selga, et kaotad või võtad ära teise isu.

Söömise ajal ei tohtinud aevastada. Kes söögi ajal aevastab, see saab kas peksa või viina, teatatakse Nõos. Tarvastus aga arvatakse, et söögi ajal aevastamine tähendab sugulase surmasõnumit. Mõistagi ei tohtinud söögi ajal haigutada, naerda, laulda ega vilistada (viimasel juhul öeldi saavat lolli mehe, "sokud lapsed ja kriimud silmad").

Laialt levinud oli uskumus, et lauas ja ka pärast sööki ei tohi ringutada või sirutada. Kes seda teeb, selle kõht hakkab valutama (Koeru), jääb tühjaks (Nõo, Tõstamaa, Tarvastu), sellel pole söömisest kasu (Muhu); selle kõhutäis läheb kellelegi teisele, näit. vanakurjale (Simuna, Kursi, Karksi, Räpina), lesenaisele (Vaivara, Palamuse), saunanaise seale (Tartu-Maarja), koerale (Jõhvi) või “vaeste laste toidujatkuks" (Tartu-Maarja). Saaremaal arvati, et söögilauas ringutaja ajab oma laiskuse teistele.

Sobivaks ei peetud ka lauale toetuda. Eriti küünarnuki lauale panek oli kõvasti keelatud. Ka ei liigutatud jalgu. Kui kogu pere jalad kenasti ühtmoodi laua all seisid, siis pidi tulema hea rukkiaasta. Kes söögiajal jalgu õõtsutas, see öeldi kiigutavat vanakurja last (teated üle maa).

Süüa ei tohtinud pimedas, ilma tuleta - siis saavad lastest vargad või saad musta näoga lapsed. Sööja suhu ei vahita - suu hakkab vett jooksma. Ka heideti ette, et "loed sööja suutäisi". Samuti ei tohi vaadata sööja - eriti laste - silma, muidu saab sellest kuri inimene. Süüa ei tohtinud pikkamisi - lehma nisad lähevad kõvaks, ei saa piima kätte. Ent on ka endeid, et aeglasest sööjast saab vaene peremees. 
Söögiajal ei käidud toast sisse-välja - see toob toidule kadu. Usuti, et kui söögiajal lahkud, saad teel peksa või pahandada. Ka ei õnnestu see, mida lahkuja tahab.

Enne kui sööma hakati, anti esimene leivasuutäis koerale: "Koera käpa all kasvab leib” (Rapla). Väga levinud oli uskumus, et kui söömisel (esimene) leivapala või suutäis suust maha kukub, siis tuleb näljane külaline või võõras. Selle kõrval üksikteade ennustab õnnetust lähemal ajal, kui leib suust maha kukub (Haljala, Kose). See ülemaaliselt tuntud uskumus on hiljem mitmeti diferentseerunud. Suust kukkunud pala ennustas näljase külalise kõrval veel ahnet külalist (Tõstamaa) või vanemat külalist (Emmaste) või lihtsalt külalist, ka santi. Ent sellele on antud muidki tähendusi: surmasõnumit (Viljandi), sõimu, riidu, kiskumist (Tallinn). Loogiline on seletus, et kui sööjal leib suust maha kukub, pole sööjal kõht tühi (Palamuse). Omapärane on seletus, et kõige lähema või armsama inimese kõht olla tühi, kui toit suust maha kukub (Simuna, Ambja).

Peamiselt Ida-Eestis levis uskumus, et joodikust mehe või naise saab see, kes söömisel lusikast lauale või rinnale tilgutas (Kodavere, Põlva, Nõo, Rõuge, Räpina, Vastseliina, Lutsi, Otepää, Sangaste, Tarvastu). Mõni üksikteade on resoluutsem: kes süües lauale tilgutab, on joodik (Põlva), kes süües rinnale tilgutab, saab tatised lapsed (Maarja-Magdaleena).

Ülirohkesti on endeid selle kohta, mida toob kaasa toidupala kurku minemine, nii et sööja läkastab. Üldiselt ennustab see halba, nimelt saab sööja (veel samal päeval) tapelda või tõrelda (tuntud üle maa, välja arvatud KaguEesti). Üksikteated ennustavad ka näljaseid võõraid (Simuna), peksasaamist (Viljandi, Helme, Kambja, Otepää, Sangaste), riiduminemist (Kihelkonna), kaklemist (Karksi). Siingi on uskumus ajapikku eristunud ja täpsustunud. Näiteks usutakse Märjamaal: "Kui süies toit hingekurku läheb ja köhima ajab, siis öeldakse: “Tuleb külalisi!” ehk "Saab teiste käest tapelda!” Kui nii köhima paneb, et silmist vesi tuleb, siis: "Saab ea nahatäie riielda!" Nõost teatatakse: "Lähäb süük alustusen kurku - saab tõrelda, kui viimate - sis viina!" Põlvas võetakse aluseks sööja vanus - kui noorel läheb söök kurku, siis saab ta peksa, kui vanal - siis saab see viina. Maarja-Magdaleenas tehakse teistpidi vahet: "Kui süües täie kõh uga (m.s. Ü. T.) kurku läheb - siis saab viina, kui tühja kõhuga - tõrelda!" Saardes jälle arvatakse: "Kui leiva suutäis kurku läheb - peab viina saama, kui supi suutäis - siis tapelda!" Kambjas tehakse nii loogiline otsustus: "Kui süük kurku lätt, siis saat tõrõlda, kui juuk - sis viina". Võimalus - saada viina või riielda (e. tapelda e. tõrelda e. peksa jne.) on levinud eeskätt Kagu-Eestis (Põlva, Rõngu, Räpina, Helme, Võru, Vastseliina, Rõuge, Sangaste, Võnnu, Otepää), kuid üksikteateid on laiemaltki alalt (Saarde, Kirbla, Kaarma, Karja). Ilmselt on tegu teatava ühtlustumisega e. assimileerumisega, 
kui kurku läinud leivapala ennustab näljast võõrast (Jõhvi, Simuna, JärvaJaani, Torma, Kodavere, Laiuse jm.). Usutavasti on see enne algselt seotud suust kukkunud leiva- või söögipalaga.

Ühesõnaga, igaüks pidi söömisel hoolas olema, et toitu maha ei kukuks ega hingekurku ei läheks. Ka ei sallitud kapast või kannust lurinal rüüpamist ega kõvasti matsutades söömist.

Huvitav on üldlevinud tava, et ei võeta uut leivatükki, kartulit, lihalõiku jne., kui eelmine leivatükk on veel pooleli või hoopiski söömata. Sel puhul arvati, et söögipala võtja armukesel (peigmehel, pruudil, parimal sõbral) on kõht tühi (Haljala, Rakvere, Tapa, Muhu, Maarja-Magdaleena) või on perekonna üks liige (kõige lähem)) söömata (Kadrina, Ambla, Tallinn, Torma, Palamuse, Põltsamaa, Võnnu, Lutsi) või on mõni tuttav söömata (Kodavere). Mõnikord küsiti leivatüki võtjalt otse: no kas su pruut-peigmees (öeldi ka nimi) on näljas või! See oli muidugi piinlik ja seepärast ka välditi tava vastu eksimist.

Hõredalt, ent peaaegu üle maa on teateid sellest, et keset söömist või siis kui suutäis veel suus - ei tohi juua. Ähvarduste skaala kombe vastu eksimisel on lai: ihule löövad paised (Tõstamaa) või vistrikud (Tõstamaa); kahepoolsed ajavad üles (Simuna); vanaks saades käivad põletsed (e. tülitsed - s.o. kõrvetised) kurgust üles (Viljandi); suu läheb kärna (Tõstamaa); toob nälja majja (Karja); lehm hakkab lüpsi ajal kusema (Karksi ja Vigala, viimases rõhutatakse - leeme juurde joomisel) ja lõpeks hinnanguline iseloomustus: kes seda teeb, on isune inimene ega saa iial täis (Põltsamaa, Halliste).

Hoolikalt tuli jälgida sedagi, mida söögilauas rääkida. Söögilauas ei tohtinud unenägusid rääkida, muidu minevat nad täide (Pärnu-Jaagupi). Söögilauas ja üldse söömise juures ei tohtinud nimetada loomi, eriti metsloomi. Kui oligi otsene tarvidus ühe või teise looma nimetamiseks, siis kasutati vastava looma peitenimetust. Peaaegu kõikide loomade nimetamisest kardeti kahju ja kadu nii viljale kui karjale. Peale selle oli igal loomal oma n.-ö. spetsiaalne kahju. Näiteks karu nimetamisel pidi hakkama härg lehma, oinas utte ja orikas emist vihkama (Karja). Hundi nimetamine pidi tekitama nimetatus suure söögihimu, nii et ta tuleb sinna, kus teda nimetati, karja kahjustama (teateid üle maa). Rebase nimetamine kutsub rebast kanavargile (Haljala). Jänese puhul arvati (lisaks orase ja puude kahjustamisele), et ta sööb seened ära (Maarja-Magdaleena) või toob haiguse majja (Torma). Hiirest kardeti, et ta närib viljakotid katki (Kolga-Jaani, Tarvastu, Maarja-Magdaleena) või tuleb toidu kallale (Torma, Palamuse, Maarja-Magdaleena, Setu). Veel keelati nimetada rotti (närib ja rikub), konna (teeb viljale kahju), kassi (kahjustab põldu), metskitse, mutti, siga, varest ja kulli. Tuntumad peitenimed olid: karul - laikäpp, hundil - pajuvillem, pajuvasikas, metsasõnn, jänesel - kontjalg, kargaja, hiirel ja rotil - sitanina, 
joosik. Juba uueaegsem näikse olevat keeld söögiajal nõelussist rääkida, sest uss armastavat ennast näidata, kui temast söögiajal räägitakse (Tallinn).

Lisaks neile, laialt levinud tavadele kohtame rohkesti haruldasi või ka lokaalseid söömisega seotud uskumusi. Olgu järgnevalt toodud mõned huvitavamad üksikteated.

Saardest on teade: "Kui süües ammas suust peaks ära minema, siis saada selles perekonnas see lapse surma ette kuulutama".

Levinum, kuid mitte üldine on teade, et "süües ära suutäit pooleli jäta, muidu kutsud vaesust tuppa" (Haljala). Üpris loomulik - ja vist selle tõttu ka vähe noteeritud on teade Jämajast: "Lapse sööma jäänuseid ei tohtivat keegi muu ära süüa kui ainult lapse ema. Kui kõrvaline isik seda teeb - süüa ta lapse söömaisu ära!"

Vanemad teated (möödunud sajandi keskpaigast ja viimasest veerandist) kinnitavad: "Ära jäta suutäit järele, siis kaob söögi isu”. See ongi meie talupoeglikule kultuurile omane ja mõistetav. Püsib ju tänaseni uskumus, et kui kõik liuad ja taldrikud tühjaks süüakse - eriti külaskäigul - siis tuleb järgmisel päeval ilus ilm. Seevastu sajandivahetusel ja käesoleval sajandil ilmuvad - ja seda eeskätt linnades - teated, et süües-juues tuli midagi, kasvõi suutäis, taldrikule jätta. Muidu minevat söögijätk kaotsi. See on ilmselt rahvusvaheline, linnades levinud tava.

Üldlevinud komme oli iga pakutud või võetud toidu (leib, liha, vorst jm.) eest lausuda "Aitüma”. Ka söömise lõpetamisel sõnati "Aitüma”. Pärast viimast aitüma ei tohtinud enam süüa, või said raske haiguse (Vändra, Saarde, Tõstamaa, Sangaste, Põltsamaa, Tartu-Maarja, Tarvastu, Vastseliina).

Meie üldiselt kehvadele oludele vastavalt on ka võtteid, kuidas külaliste söögiisu vähendada või üldsegi kaotada. Kõige levinumaks võtteks oli pruuk, millest jutustab Torma teade: "Et võerad inimesed ehk kostilised palju ei sööksivad, olla tarvis nende söögiisu vähendamiseks surnuaiast risti seest raudnael tuua ja see söömalaua sisse lüüa. Kui kostiline samase laua pealt paar suutäit sööb, siis olla ta söömaisu kadunud. Oma maja inimestele ei pidada see aga pahasti mõjuma”.

See on suurtes joontes kõik, mida võib öelda söögitavadest. Muidugi võiks siia lisada hulganisti üksikteateid, samuti uuemaid kombeid (näiteks, miks ei tohi söögi ajal lugeda), kuid need teeksid üldpildi ainult kirevamaks. Arvestada tuleb sedagi, et vastavaid tavasid pole uuritud. Midagi kindlamat saaksime öelda aga ainult uurimise ja nimelt võrdleva uurimise põhjal. 


\section{5.}

Teadupärast oli omal ajal - ja on enamasti praegugi - kolm söögikorda: keskhommik, lõuna ja õhtu. Et söögiaegade vahe oli pikk, tekkis vajadus ka vaheaegadel n.-ö. suurust võtta. Ka nendel puhkudel olid omad kindlad tavad, millal võis süüa ja millal mitte.

Üle maa oli tuntud komme hommikul enne tööle minekut võtta linnupetet. See tähendas, et tühja kõhuga ei tohtinud kuulda kas üldse linnu või mõne teatava linnu laulu - lind pettis sind ära. Selle vältimiseks söödi püstijalu tükk leiba - see oligi linnupete.

Ent oli muidki tavasid. Teel olles ei tohtinud süüa, eriti oli keelatud tee peal (s.o. leivakott asetatud teele) süüa. Keeldu põhjendati - surnud (sest teed mööda on viidud surnuid) võtavad leiva jätku (Otepää), vastutulijad võtavad isu (Suure-Jaani). Teise tallu ei tohtinud süües minna - sa viid oma rotid kaasa ja tekitad nii pahandust perede vahele (Saaremaal ja Lutsis tuttav).

Süüa ei tohtinud kaevule minnes ja kaevust vett võttes. Kaevuteel ei tohtinud sööki käes olla kõnelemata selle suus närimisest. Põhjenduseks tuuakse: kaevu sigivad rotid (Tartu-Maarja, Setu) ja hiired (Laiuse, Torma, Lutsi), konnad (Tallinn, Karuse, Maarja-Magdalena, Äksi) ja ussid (Simuna). Üksikteated nimetavad, et kaevu kukuvad surnud hiired või igasugu loomad. Ka sööjat ähvardas oht kaevu kukkuda (Järva-Jaani).

Süüa ei tohtinud toalävel - söögiõnn läheb majast (Räpina) või kosilased pöörduvad tagasi (Torma, Tartu- Maarja). Süüa ei tohi ka lauta minnes või isegi lauda poole minnes. Kui seda teed, siis loomad lähevad kurjaks, pusklevad, tõmbavad lõast lahti (Tallinn, Karuse, Karksi) või kaob loomade isu (Kadrina, Simuna).

Kangakudumise juures ei tohi süüa - sellest kangast tehtud särki sigivad täid (Kolga-Jaani, Torma, Järva- Jaani). Mõnel pool ei tohtinud isegi ülesseatud kanga ees süüa - ikka samal põhjusel: kangast tehtud särki sigivad söödikud (Kursi) või rotid närivad puruks sellest kangast tehtud kotid (Põltsamaa). Väga levinud on uskumus, et sööd kanga koe ära, koest tuleb puudus (Saaremaa, Tartumaa, Tarvastu).

Ka ketramise ajal ei tohtinud süüa - sööjate soolikad lähevad kurku või segamini, sööjad ei jaksa süüa, isu kaob, kõht jääb kinni (teateid rohkesti Kesk-Eestist). Samuti ei olnud hea õmblemise ajal süüa - nõelub soolikad kokku, õmbleb kõhu väikeseks (Halliste, Maarja-Magdaleena). Vististi kanga ees söömise keelust ülekantud on uskumus, et õmblemise ajal süües sigivad täid riietesse (Kolga-Jaani ja Rõngu). Kõvasti oli keelatud söömine rehetoas, kui vili oli parsil kuivamas. Keelu rikkumine põhjustas terade hallitamist. 
Süüa ei tohtinud ka külimitu või vaka peal istudes. Kes seda tegi, see oli eluaegne võlgnik (Tartu-Maarja) või sööb võlgu (Põltsamaa) või jääb suurtesse võlgadesse (Torma, Viljandi). Ülepea ei tohi süüa tühja ehk õonsa riista peal sööja kas ei saa kõhtu täis (Ambla) või maksab eluaeg võlgu (Palamuse).

Muidugi on rohkesti mitmesuguseid kombeid seoses toidutegemisega. Iseäralikult rohkesti kombeid ja uskumusi on seotud leiva valmistamise, hoidmise ja söömisega. Neid on sedavõrd ohtrasti, et pole mingit võimalust neist ülevaate andmiseks selle artikli piires. Leivaga seotud uskumused ja tavad nõuavad omaette käsitlust. Niipalju märkigem, et rohked kombed viitavad selgesti asjaolule, et leib oli eestlaste põhitoidus pikki aegu. Kuna aga põlluvili ikaldus - kas siis kliima, agrotehnika või mõisaorjusest tingitud suutmatuse tõttu - peaaegu perioodiliselt (kui mitte üle aasta, siis üle kahe-kolme), siis olid eestlased kogu aja kas päris näljas või nälja piiril. Küllap on õigus nendel, kes väidavad, et alles kartulikasvatamisega pääsesid eestlased pidevast alatoitlusest. Sellest siis ka rohked leiba austavad, lausa pühaks pidavad pruugid. Iseloomulik on teade Märjamaalt, veel 1958. aastast: "Leib on toidu peremees. Sööma hakates pidi ikka kõige enne tükikese leiba suhu pistma, siis võis leivakõrvast võtta!”

Tänapäeval lüüakse suurt lärmi kui leivast resp. saiast leitakse mõni võõrkeha (paelajupp vms.). Huvitav on täiesti vastandlik suhtumine nähtusse möödunud sajandil ja veel käesoleva sajandi alguseski. Uskumus avaldub vanasõnas "Kui sina leiba häbistad, siis leib häbistab sind". Lahtimõtestatult tähendas see, et kui sööja leiab leivast mõne võõrkeha (õlekõrs, agan, kärbes) ei tohi sellest rääkida, s.o. ei tohi leiba häbistada, muidu leib häbistab sind, s.o. leib kaob majast (ehk nälg tuleb majja). Uskumus on laialt tuntud. Mõnes hilisemas teates on küll häbistamise viis muutunud - nimelt sunnib häbistatud leib oma häbistajat söögi ajal peeretama, millega too üldise pilke ja põlguse alla satub. On ka kohti (Karksi, Viljandi, Kolga-Jaani, Helme), kus see uskumus laieneb leivalt söögile, sest võõrkeha võis leiduda ka supis või pudrus.

Leiva esinemisest ka üpris kauges tseremoonias või rituaalis annab tõendi järgmine teade Palamuselt: "Peale ristimist ei tohi vaderid enne viina juua, kui piavad enne suutäis leiba sööma - siis on (risti) lapsel eluaeg leiba ega saa tast joodikut".

Väga iseloomustavad leiva austamisele on järgmised teated. Suure-Jaanist teame, et selga ei tohi pöörata ahju poole, kui leivad ahjus on. Keelu rikkujale (lastele, sest vanad olid keelust juba teadlikud) kasvab küür selga. Leiba ei tohi murda ühe käega (s.o. hooletult). Ühe käega võib leiba murda ainult imetav naine (Kuusalu, Pärnu- Jaagupi, Kanepi).

Eelmainitud mõne näitega olgu ainult vihjatud leivauskumuste väga laiale ringile. Mõistagi on kombeid ja uskumusi toidutegemisest ja toiduainete (näit. või) valmistamisest. Ent kõik need tavad ei mahu käesoleva ülevaate raamidesse. 
Lõpetuseks veel mõni sõna muistsest nädalasest menüüst eesti talus. Nimelt valitses eesti talus traditsiooniline toidusedel. Igal päeval oli oma roog. Muidugi mõeldakse traditsioonilise roa all sooja sööki, mida tehti kas lõunaks või koguni õhtuks. Hommikusöök e. keskhommik oli tavaliselt umbes kell üheksa, lõuna kell neliteist ja õhtusöök kell kakskümmend.

Esmaspäevane roog oli tangusupp (Kesk-Eestis), piimasupp, jahupuder (Audru) ja ainult Viru-Jaagupist on teada, et esmaspäevane roog olnud hernesupp.

Teisipäeval oli valdavalt kartulisupp (lihaga) - samal alal, kus esmaspäeval oli tangusupp. Erandiks on Viru- Jaagupis tangusupp ja Amblas ning Põltsamaal hernesupp.

Kesknädalal oli valdaval alal roaks tangupuder. Ainult Amblas ja ViruJaagupis nimetatakse kesknädalaseks roaks kartuliputru (mis saabki olla suhteliselt hiline, kartul tuli ju meile alles möödunud sajandil.

Neljapäevaseks roaks oli kapsasupp (lihaga). Mõnel pool märgitakse ka kartulisuppi (Ambla, Järva-Madise, Audru) või hernesuppi (Paide).

Reedene roog pole enam nii kindel, vaid kihelkonniti tublisti erinev. Põltsamaal, Amblas, Järva-Madisel ja Türil on selleks hernesupp, Audrus kartuli- või jahupuder, Viru-Jaagupis oasupp, Paides tangusupp.

Laupäeva roaks on valdavalt tangupuder. Ainult Amblas ja Järva-Madisel nimetatakse ka kartuliputru ja Pärnus liha- või piimasuppi.

Pühapäeva roaks oli valdavalt kapsasupp.

Näeme, et kattuvad kesknädalane ja laupäevane söök, samuti neljapäevane ja pühapäevane roog.

\section{6.}

Seega oleme põgusalt üle vaadanud argielu mõne tahuga seotud kombed ja viimastega seostuvad uskumuslikud ended. Kindlasti pole suudetud hõlmata kogu olemasole- vatki materjali. Teisalt on kindel, et kaugeltki kõigi nähtuste ja sündmuste kohta pole rahvaluulekogudes teateid kõigist paikadest. Kui lugeja leiab, et mõni temale tuntud tava või pruuk on kirjutises kajastamata, siis teeb ta õigesti, kui teatab sellest Kirjandusmuuseumi rahvaluuleosakonda (202 400 Tartu, Vanemuise 42, TA Fr. R. Kreutzwaldi nimeline Kirjandusmuuseum, rahvaluule osakond). Igatahes ärgu pandagu kirjutises esinevaid puudujääke rahvaluulekogude kaela. Vastutab eeskätt autor, kes pole olemasolevat materjali suutnud küllaldase põhjalikkuse ja süvenemisega käsitleda. Igatahes on algus tehtud ja järgnevatel käsitlejatel sedavõrra lihtsam. Pole aga kahtlust, et argielutavad, mis ühelt poolt juurduvad kaugesse minevikku ja teiselt poolt elavad - vähemalt osalt - veel tänapäevalgi, on vägagi huvitav uurimisala, mis ootab käsitlemist ja tutvustamist. 